\title{
—Tea Fumić
}

\section{Kult Jupitera Heliopolskog u Sisciji}

\begin{abstract}
Kult Jupitera Heliopolskog jedan je od sedam „orijentalnih“ kultova koji su zasad potvrđeni epigrafskim i predmetnim izvorima u antičkoj Sisciji. Na žrtveniku konzularnog beneficijara Lucija Virilija Pupa nalazi se natpis posvećen Jupiteru Heliopolskom, na kojem piše da se ne smiju žrtvovati svinje. U radu ćemo nastojati ustanoviti je li zabrana svinjetine u kultu Jupitera Heliopolskog bila uvriježena kultna praksa, nastala prema sirijskim običajima. U svjetlu podataka s ovog spomenika nastojat ćemo odgovoriti na pitanje u kojoj mjeri kult možemo smatrati rimskim ili ,orijentalnim“.
\end{abstract}

\section{Uvod}

Kult Jupitera Heliopolskog jedini je sirijski kult zasad potvrđen u Sisciji žrtvenikom konzularnog beneficijara Lucija Virilija Pupa. ${ }^{1}$ Formulacija o zabrani žrtvovanja svinja jedinstvena je u smislu da joj ne nalazimo analogiju u opsežnoj epigrafskoj građi s područja cijelog Carstva. Cilj je ovog rada utvrditi je li zabrana žrtvovanja svinja službena kultna praksa ili je dedikant iz osobnih razloga na ovaj način izrazio svoju averziju prema životinji. Pritom ćemo na primjeru heliopolskog kulta ukazati na problem determiniranja izvornih, odnosno predrimskih elemenata tzv. „orijentalnih“ kultova koje poznajemo uglavnom na temelju interpretatio Romana. ${ }^{2}$ Stoga ćemo u ovom radu prikazati i pregled povijesti kulta u kojemu se ističu elementi mogućeg autohtonog karaktera.

\section{CIL III: 3955 .}

2 U posljednjih se nekoliko godina učestalo raspravlja o fenomenu „orijentalnih“ kultova, s tendencijom odmaka od koncepta F. Cumonta koji pretpostavlja homogen „orijentalni“ identitet i religijski sustav te ga suprotstavlja rimskom (v. VERSLUYS 2013; MOL 2015; GILMEISTER I MUSIAL 2017). Moderna historiografija nastoji reinterpretirati spomenike „orijentalnih“ kultova kako bi se ukazalo na mogućnost da ih Rimljani nisu preuzeli u njihovu izvornom obliku. Prema njima, „orijentalna“ božanstva, u obliku u kojem ih poznajemo u rimskom kontekstu, treba smatrati rimskom tvorevinom, pogotovo kada ih javno promovira rimska vlast. M. Versluys smatra da kultne prakse, koje su u rimskom kontekstu specifične, odnosno „orijentalne“, treba držati rimskim produktom, nastalim namjerno. Drugim riječima, ti kultovi nisu „orijentalni“" sami po sebi, već su u određenim aspektima takvima načinjeni (VERSLUYS 2013: 240, 242). 


\section{Jupiter Heliopolski}

Jupiter Heliopolski romanizirano je božanstvo semitskog podrijetla, čiji kult potječe iz Heliopola, današnjeg Baalbeka, smještenog u dolini Beka'a u istočnom Libanonu. Predrimska prošlost grada još je uvijek velikim dijelom nepoznata, prvenstveno zbog manjka pisane i materijalne građe. Iako je krajem 19. te tijekom 20. stoljeća na lokalitetu provedeno nekoliko arheoloških istraživanja ${ }^{3}$, tek su recentna iskopavanja potvrdila naseljenost od razdoblja pretkeramičkog neolitika do željeznog doba. ${ }^{4}$ Malo je podataka i o helenističkom Heliopolu. ${ }^{5}$ Pretpostavlja se da su ga u 3. stoljeću pr. Kr. osnovali Ptolomejevići ${ }^{6}$, na što ukazuje i samo ime grada (Lukijan ga povezuje s donjoegipatskim Heliopolom). ${ }^{7}$ Prema pisanim izvorima, rimska je aktivnost na području grada započela još u vrijeme kada se Pompej navedenim prostorom koristio za kontrolu Iturejaca. ${ }^{8}$ Rimski Heliopol u početku je teritorijalno pripadao koloniji Berit, današnjem Bejrutu ${ }^{9}$, sve do kraja 2. ili početka 3. stoljeća, kada ga Septimije Sever proglašava samostalnom kolonijom (Colonia Iulia Augusta Felix Heliopolis). ${ }^{10}$ Pretpostavlja se da je rastuća popularnost kulta Jupitera Heliopolskog uvelike utjecala na odvajanje Heliopola od matične kolonije. ${ }^{11}$ Kult se na zapad širi u prvoj polovini 2. stoljeća, sudeći prema pouzdano datiranom epigrafskom materijalu s prostora Dakije ${ }^{12}$ i Kampanije ${ }^{13}$ te kultnim svetištima u Rimu i Karnuntu koja su već u drugoj polovici 2. stoljeća bila u upotrebi. ${ }^{14}$ Prema trenutnom stanju istraživanja, najveći broj spomenika i kultnog materijala (izvan Sirije), kao i hramskih objekata, pronađen je na prostoru Rima, Gornje Panonije te 1 . italske regije. ${ }^{15}$ Kult su ponajviše širili

\footnotetext{
WIEGAND 1921: 1-12; RAGETTE 1980: 81-99.

4 ESS 2008: 99-121.

5 SAWAYA 2005: 147-148.

6 MILLAR 2006: 179.

7 Luc. Syr. D. 5.

8 Joseph. AJ. 14. 3. 2; Plin. HN. 5. 80; Strab. 16. 2. 10.

9 JONES 1971: 270; MILLAR 2006: 177.

10 MILLAR 2006: 177; ISAAC 2017: 264.

11 O međusobnom odnosu Berita i Heliopola te ulozi kulta $\mathrm{u}$ administrativnoj podjeli teritorija $\mathrm{v}$. REY-COQUAIS 1967: 34-35; JONES 1971: 226-295; MILLAR 2006: 164-223.

CIL IV: 1353.

13 AE 2006: 312.

14 STEIGBERGER I TOBER 2013: 436; GRAINGER 2017: 228.

15 U Gornjoj Panoniji pronađeno je devet spomenika (CIL III: 3908, 11131, 11139, 11137, 11138, 3955; $A E$ 1974: 496; $A E$ 1982: 774; $A E$ 1988: 931). Osam je spomenika pronađeno u Rimu (CIL VI: 36791, 36792, 36793, 30764, 422, 423; $A E$ 1984: 452; $A E$ 1988: 209). Na prostoru 1. italske regije pronađeno je sedam spomenika, pet u Puteoliju (CIL X: 1578, 1579; $A E$ 1899: 33; $A E$ 2006: 312; Eph. Ep VIII: 359) te dva u Ostiji (CIL XIV: 24; $A E$ 1988: 274).
} 
sirijski doseljenici, trgovci, vojnici i robovi koji su se još od vremena Trajana, a osobito nakon Markomanskih ratova, u velikom broju doseljavali na područje Panonskog bazena. ${ }^{16}$ Period od druge polovine 2. stoljeća pa sve do sredine 3 . stoljeća možemo smatrati razdobljem kada je popularnost kulta bila na vrhuncu. Od sredine 3. stoljeća broj spomenika opada, a istraživanja svetišta ukazuju na postupno smanjivanje kultnih aktivnosti, premda su ona u upotrebi sve do sredine 4. stoljeća. ${ }^{17}$

Gotovo da i nema podataka o semitskoj prošlosti božanstva. Moguće je da se rimski Jupiter Heliopolski oslanja na željeznodobna božanstva Tešuba i Hadada, s kojima u prikazima dijeli i neke ikonografske atribute poput munja i bikova. ${ }^{18} \mathrm{U}$ obzir treba uzeti i utjecaj različitih lokalnih božanstava koja nose pridjevak ba'al, u značenju 'gospodar' ili 'vlasnik', što je titula koja je označavala božansku prirodu. Lokalni ba'al uglavnom se smatrao vrhovnim bogom, stoga je u rimskom smislu nerijetko identificiran kao Jupiter. ${ }^{19}$ Poznat nam je primjer kulta komagenskog Jupitera Dolihenskog koji se vjerojatno razvio iz štovanja dolihenskog Baala. ${ }^{20} \mathrm{U}$ svakom je slučaju romanizacija semitskog pretka Jupitera Heliopolskog morala započeti rano, rimskim osvajanjem Berita u drugoj polovici 1. stoljeća pr. Kr., $\mathrm{s}$ obzirom na to da je već u prvoj polovici 1. stoljeća započeta gradnja hrama $\mathrm{u}$ Heliopolu. ${ }^{21}$

Zbog rane romanizacije kult poznajemo isključivo $\mathrm{u}$ rimskom kontekstu, a sav pisani i predmetni materijal datira iz carskog doba. ${ }^{22}$ Šturi literarni izvori ne pomažu nam u potrazi za predrimskim elementima kulta, ${ }^{23}$ stoga se treba okrenuti dostupnom predmetnom i epigrafskom materijalu koji nam je važan ikonografski izvor. Većinom su to brončane figurine, parcijalno očuvane skulpture, reljefi, žrtvenici i dekorativni kameni stupovi. ${ }^{24}$ Analizom ikonografije suočavamo se s problemima koji otežavaju determinaciju autohtonih i sekundarnih ikonografskih

\footnotetext{
FITZ 1980: 151-152.

STEIGBERGER I TOBER 2013: 435; GRAINGER 2017: 213.

8 KUSSEVEN 2007: 33.

19 Ibid.

20 SANDERS 1902: 84.

21 LOHMANN 2010: 23

22 KROPP 2009: 365.

23 Jedini literarni izvor koji donosi nešto više informacija o heliopolskim bogovima Makrobijeve su Saturnalije (Saturnalia) (Macrob. Sat. I. 23). Usputno Jupitera Heliopolskog spominju i već navedeni Lukijan (Luc. Syr. D. 5), Euzebije (Euseb. Praep. Evang. 4. 16. 22; Vita. Const. 3. 58; Theophania 2. 14) i Damascije (Dam. Isid. 203).

24 Većina materijala objavljena je 1977. i 1985. godine, u seriji Y. Hajjara La triade d'HeliopolisBaalbek. Određen dio materijala ne može se sa sigurnošću pripisati heliopolskom kultu, na što u posljednjih nekoliko godina objavama upozorava A. Kropp (KROPP 2009: 365-380; IDEM 2010: 229-264), koji je objavio i novi materijal (IDEM 2012: 141-150).
} 
elemenata. Naime, prikazi Jupitera Heliopolskog nisu ikonografski kanonizirani, u smislu da ne postoje dva identična prikaza božanstva. Dodatno, analiza ikonografije ukazuje da su u prikazima u manjoj mjeri zastupljeni atributi koje možemo okarakterizirati kao rimske. To su u prvom redu uski, bogato ukrašeni ogrtač (ependytes), oblikovan tako da oponaša rimski prsni oklop, te ogrtač koji imitira kratke kožne rukave s resama i prsno remenje (epomis). Prikazi munje, osnovnog i prepoznatljivog atributa rimskog Jupitera, iznimno su rijetki i pojavljuju se uglavnom na gemama i kamejama. ${ }^{25}$ U najvećoj su mjeri zastupljeni atributi izrazito egipatskog karaktera (sunčev disk, kalat, egipatska dvostruka kruna) ${ }^{26}$ koji bi mogli potvrditi navode Makrobija i Lukijana o egipatskom podrijetlu božanstva i vezi s egipatskim Heliopolom. ${ }^{27} \mathrm{Tu}$ vezu dodatno naglašavaju i neki atributi Venere Heliopolske (sfinge, kalat, sunčev disk, rogovi božice Hator), koja je zajedno s Jupiterom i Hermom tvorila kultnu heliopolsku trijadu. ${ }^{28}$ Mogući semitski atribut izdvojio je A. Kropp, analizirajući ogrtač (ependytes) za koji smatra da ne treba isključivo tvrditi da imitira rimski prsni oklop jer je takav i u iturejskoj ikonografiji. ${ }^{29}$ Tako su iturejski božanski blizanci, koji nose arapska imena, prikazani kao Dioskuri u prsnom oklopu na novcu iz Halkide, sjedištu iturejskih vladara, koji datira iz 73. godine pr. $\mathrm{Kr}^{30}$ Iturejci su početkom 1 . stoljeća pr. Kr. uspostavili tetrarhiju u današnjem Libanonu te su neko vrijeme vladali i Heliopolom. ${ }^{31} \mathrm{~S}$ obzirom na to da su se iturejski vladari nazivali i vrhovnim svećenicima, A. Kropp pretpostavlja da im je religijsko sjedište bilo u Heliopolu, jedinom većem kultnom centru unutar iturejskog teritorija. ${ }^{32}$ Iturejski numizmatički materijal glavni je izvor podataka o njihovu religijskom sustavu. Na novcu su najčešće semitska božanstva, namjerno prikazana u grčko-rimskom ikonografskom stilu kako bi iturejski novac cirkulirao širim područjem i bio prepoznatljiv što većem broju ljudi. Zbog manjka izvora nije moguće odrediti u kojoj su mjeri Iturejci utjecali na heliopolske kultove (neki su znanstvenici taj utjecaj i potpuno odbacili ${ }^{33}$ ) te uspostaviti kontinuitet između iturejskog Zeusa, koji se oslanja na semitskog Hadada ili Baalshamina, i rimskog Jupitera Heliopolskog. Ikonografski gledano, jedini semitski atributi heliopolskog

25 HAJJAR 1988: br. 14, 25, 27; KROPP 2010: 232.

26 
božanstva (ako odbacimo iturejski prsni oklop) jesu klasje žita i bič koje Jupiter Heliopolski drži u ruci te dva bika u pratnji, tipični za već spomenuta dva semitska božanstva ${ }^{34}$ Ikonografski elementi koji se u prikazima najčešće pojavljuju (klasje žita, bič, kalat) ukazuju na agrarni karakter božanstva. ${ }^{35}$ Neki su autori Jupitera Heliopolskog okarakterizirali kao solarno božanstvo, vodeći se navodom Makrobija o njegovu egipatskom podrijetlu, atributima poput sunčeva diska i zrakaste krune te toponimom Heliopol, ${ }^{36}$ dok drugi agrarni aspekt smatraju primarnim. ${ }^{37}$

\section{Siscijska posveta}

Žrtvenik Lucija Virilija Pupa dragocjen je izvor za istraživanje kulta Jupitera Heliopolskog. Žrtvenik je prvi objavio T. Mommsen. ${ }^{38}$ Pripremajući objavu trećeg sveska $C I L$-a, Mommsen je posjetio Sisak 1873. godine. ${ }^{39}$ Tom je prilikom zabilježio natpise petnaest siscijskih spomenika, ${ }^{40}$ od kojih su neki već u njegovo vrijeme bili izgubljeni. ${ }^{41}$ Podatke o njima crpio je iz izdanja i bilješki starijih autora, prvenstveno A. Blaškovića, M. P. Katančića i I. Tkalčića. ${ }^{42}$ Spomenik Lucija Virilija Pupa jedan je od tri koje je Mommsen vlastoručno transkribirao, ${ }^{43}$ navodeći da je spomenik bio ugrađen u zidine sisačke utvrde Stari grad (Sisciae in arce) ${ }^{44}$ čija je gradnja počela 1544. godine, uz obilno korištenje građevinskog materijala antičke Siscije. ${ }^{45}$ Spomenik je uništen prilikom saniranja kamenih žljebova sisačkoga kaptolskog svratišta. ${ }^{46}$ Budući da je Mommsen spomenik zatekao

\footnotetext{
34 KROPP 2009: 372.

35 IDEM 2010: 240.

36 O solarnom apektu kulta v. FICK 1999: 77-99; HAIDER 1999: 101-143; FREYBERGER 2000: 95-113.

37 O agrarnom aspektu kulta v. SEYRIG 1971; HAJJAR 1985: 205-217; IDEM 1990: 2480-2482.

38 CIL III: 3955.

39 AIJug I: 239.

40 CIL III 3947, 3948, 3949, 3950, 3955, 3958, 3960, 3962, 3964, 3965, 3983, 3987, 3989, 3993, 3995.

$41 \quad$ Ibid. 3950, 3958, 3960, 3962, 3983.

42 VUKELIĆ 2011: 50-55, 130-132.

43 AIJug I: 239.

44 CIL III: 3955; HAJJAR 1977: 336; SELEM 1980: 270.

45 VUKELIĆ 2011: 27.

46 RENDIĆ-MIOČEVIĆ 2005: 249. Ubrzo nakon objave u CIL-u, tekst natpisa je stručnoj javnosti predstavio H. Dessau u korpusu Inscriptiones Latinae Selectae (ILS 4293). Opširnija objava uslijedila je tek 1977. godine u kapitalnom dvotomnom djelu Y. Hajjara o tzv. heliopoljskoj trijadi bogova (HAJJAR 1977: 336-338, br. 279). U međuvremenu se kratko na spomenik osvrću i J. Toutain (TOUTAIN 1911: 52, 60) te V. Hoffiler i B. Saria (AIJug: 239). Kraće interpretacije spomenika objavili su i P. Selem (SELEM 1980: 270-271, br. 2.) te A. Rendić-Miočević (RENDIĆ-MIOČEVIĆ 2005: 249). Usputno ga navodi i M. Šegvić u svom radu o antičkim
} 
sekundarno iskorišten, nepoznata nam je njegova izvorna lokacija, kao i fizičke karakteristike (dimenzije, stilizacija natpisnog polja i slova, ikonografski prikazi i sl). Tekst natpisa sačuvan je u cijelosti i glasi:

\author{
I(ovi) O(ptimo) M(aximo) \\ HELIOPOLITANO \\ L(ucius) VIRILIVS \\ PVPVS B(ene)F(iciarius) CO(n)S(ularis) \\ 5 V(otum) S(olvit) L(ibens) M(erito) \\ NE QUIS IN HAC \\ ARA PORCOS AGI \\ FACERE VELIT \\ Jupiteru Najboljem i Najvećem \\ Heliopolskom \\ Lucije Virilije \\ Pup, konzularni beneficijar, \\ 5 ispunio je zavjet rado i prema zasluzi. \\ Da nitko ovome \\ žrtveniku svinje ne dovodi, \\ htio bi. ${ }^{47}$
}

U 2. retku upotrijebljene su ligature na slovima He i lit. Varijaciju u čitanju donosi jedino Rendić-Miočević pa prema njemu 6. i 7. redak natpisa treba čitati ovako: ne quis hac / aram pondos sacrum. ${ }^{48} \mathrm{U}$ autora je vjerojatno došlo do pogreške $\mathrm{u}$ prijepisu teksta jer navodi da tekst natpisa preuzima iz $C I L$-a. Manju varijaciju donosi i Selem, koji smatra da 7. redak treba čitati ara porcos agit. ${ }^{49}$ Zbog trodijelne imenske formule posvetitelja, spomenik bi trebalo datirati najkasnije u 2 . stoljeće. ${ }^{50}$

Imenska formula Lucija Virilija Pupa upućuje na njegovo južnogalsko, odnosno sjeveroitalsko podrijetlo. ${ }^{51}$ Nije moguće utvrditi je li sljedbenik kulta postao prije ili poslije doseljenja u Sisciju. S jedne strane, u Sisciji je epigrafski i predmetno potvrđeno više zajednica sljedbenika „orijentalnih“"kultova. ${ }^{52}$ Vojna prisutnost na

kultovima na sisačkom i karlovačkom području (ŠEGVIĆ 1986: 96). U posljednjih nekoliko godina spominje se u nekoliko radova koji se bave tematikom konzularnih beneficijara i kultnih spomenika općenito (NELIS-CLÉMENT 2014: 194; RADMAN-LIVAJA I VUKELIĆ 2015: 403; IDEM: 210; SELEM I VILOGORAC-BRČIĆ 2018: 188, br. 21).

SELEM I VILOGORAC BRČIĆ 2018: 188, br. 21.

RENDIĆ-MIOČEVIĆ 2005: 250.

SELEM 1980: 270.

M. Sinobad datira ga u prvu polovinu 3. stoljeća (SINOBAD 2010: 209, br. 174).

BARKÓCZI 1964: 304, 321.

Najbrojniji su Mitrini spomenici (CIL III: 3958, 3960, 3959, 3977, 10841; ROMIC II: 95-103, br. 25-30) koji sugeriraju da je mitraizam bio osobito popularan na području grada. Tome u prilog 
području grada, razvijena trgovačka i prometna mreža uvjetovali su kulturološku i etničku raznolikost stanovnika, koja je oblikovala heterogeno siscijansko društvo. ${ }^{53}$ Krajem 1., odnosno početkom 2. stoljeća u Sisciju se doseljavalo stanovništvo istočnih provincija, privučeno mogućnošću stjecanja imetka na temelju prometa, trgovine i proizvodnje. ${ }^{54}$ Oni su, zajedno s vojnicima „orijentalnog“ podrijetla, promovirali i štovali „orijentalna“ božanstva u novoj domovini. Svi se spomenici i predmeti datiraju od kraja 1. do kraja 3. stoljeća, no treba naglasiti da je većina spomenika datirana u razdoblje dinastije Severa (193-235), poglavito Septimija Severa i Karakale. ${ }^{55}$

Pupov žrtvenik zasad je jedina potvrda kulta sirijskog podrijetla u Sisciji. Služba konzularnih beneficijara u određenoj beneficijarskoj postaji trajala je do oko 6 mjeseci, stoga je moguće da je Lucije Virilije Pup u određenom razdoblju svoje karijere službovao u nekom mjestu u kojemu je djelovala zajednica sljedbenika Jupitera Heliopolskog te je dolaskom u Sisciju odlučio svoju naklonost izraziti posvetom na žrtveniku. Od ukupno četrnaest beneficijara, čija je služba epigrafski potvrđena u Sisciji (deset konzularnih i četiri prokuratorska), ${ }^{56}$ jedino je Pupov žrtvenik posvećen jednom „orijentalnom“ božanstvu. Beneficijari su općenito bili naklonjeni Jupiteru, ${ }^{57}$ a većina njihovih spomenika iz Siscije posvećena je

govori i spomenik carskog roba Jukunda (CIL III: 3960; SELEM 1980: 82, br. 11; ZANINOVIĆ 1981: 203; ROMIC II: 96, br. 26), koji ističe da je izgradio portik i atrij Mitrina svetišta, koje zasad još nije arheološki ubicirano. Mitrin je kult potvrđen i predmetno, dvjema reljefnim pločama (BRUNŠMID 1905: 60, br. 120, 62, br. 121; SELEM 1980: 84, br. 15, 88, br. 16; ROMIC II: 98-103, br. 29-30) te ulomkom brončane glave za koju je moguće da predstavlja i Kibelina pratitelja Atisa (SELEM 1980: 90, br. 17; ROMIC II: 141-142, br. 8). U Sisciji su bili popularni i egipatski kultovi, posebno Izidin, koji je, uz dva epigrafska spomenika (CIL III: 3944; AIJug I: 531; ROMIC II: 38-40, br. 26-27), potvrđen i ulomkom glave skulpture koja predstavlja Izidinu svećenicu (SELEM 1980: 7, br. 8). te brončanim privjeskom s prikazom Harpokrata (SELEM 1980: 8, br. 9; ROMIC II: 41, br. 29). Ova dva nalaza sugeriraju i postojanje Izidina hrama na prostoru grada (BUZOV 2012: 69). Predmetni izvori svjedoče nam i o aktivnostima kulta Serapisa (SELEM 1980: 8, br. 10; ROMIC II: 40, br. 28) i Jupitera Amona (SELEM 1980: 9, br. 11, 12; ROMIC II: 41-43, br. 30-31,33), a treba spomenuti i danas izgubljenu figurinu sfinge (ROMIC II: 43, br. 32). Metroački je kult također imao ulogu u duhovnom životu grada. Epigrafska potvrda postojanja kolegija dendrofora (CIL III: 10858; ROMIC II: 133-134, br. 8), nositelja stabala tijekom proljetne svetkovine božice Kibele, sugerira postojanje veće zajednice sljedbenika. Od figuralnih prikaza vezanih uz kult, sačuvane su četiri brončane figurine/aplike Atisa (SELEM 1980: 202, br. 10; 203, br. 11; 204, br. 12; 205, br. 13; ROMIC II: 142, br. 9; 131, br. 5;132, br. 6; 132-133, br. 7) i jedna svjetiljka s prikazom Kibele (SELEM 1980: 205, br. 14; ROMIC II: 143, br. 11). Reljefnim pločama potvrđena je i prisutnost kulta tračkog (BRUNŠMID 1905: 56, br. 109) te dunavskog (ROMIC II: 173-176, br. 8-13) konjanika.

53 ŠAŠEL KOS 2017: 175.

54 ZANINOVIĆ 1981: 203.

55 BUZOV 2012: 67-69.

56 CIL III: 3943, 3957, 10843, 3948, 15180, 3947, 10842, 3949, 15181, 10839, 3970.

57 RADMAN-LIVAJA I VUKELIĆ 2016: 206. 
baš njemu pa je sugestivan podatak da je Lucije Virilije Pup, osoba odrasla u srcu Carstva, žrtvenik odlučio posvetiti božanstvu čije ime jasno odaje „orijentalnu“ vezu. Podrazumijeva li ta sloboda izražaja veću skupinu sljedbenika Jupitera Heliopolskog u Sisciji ili je riječ o popularnosti ,orijentalnih“ kultova tijekom vladavine dinastije Severa, možemo samo nagađati. Također možemo samo pretpostaviti da su u Sisciji postojali hram Jupitera Heliopolskog, kultni službenici i skupine sljedbenika. Pupov žrtvenik sâm po sebi ne ukazuje na postojanje hramskog objekta jer su beneficijarske postaje imale svoja svetišta, ${ }^{58}$ stoga se Jupitera Heliopolskog možda štovalo i u hramu rimskog Jupitera u Sisciji. Siscijanska beneficijarska postaja još uvijek nije arheološki ubicirana, ali se pretpostavlja da je bila smještena južno od grada, izvan njegovih zidina, vjerojatno u blizini utvrde Stari grad u kojoj su pronađeni i neki drugi beneficijarski spomenici, ${ }^{59}$ također iskorišteni kao građevinski materijal. Pupov bi žrtvenik mogao biti potvrda te lokacije zbog navoda o zabrani žrtvovanja svinjetine. Naime, prostor oko današnje utvrde bio je nekada pošumljen, a divlje su svinje slobodno lutale cijelim područjem. ${ }^{60}$ Moguće je i da su siscijski uzgajivači svinja dovodili svoja krda u hrastovu šumu pokraj utvrde na ispašu, tj. žirenje. Ti su prizori mogli uznemiriti sljedbenika kulta u kojemu su se svinje smatrale nečistima ili bile zabranjene. Budući da je žrtvenik zasigurno stajao na otvorenom prostoru, vjerojatno je s dedikantove strane postojala i bojazan da će lutajuće svinje oskvrnuti spomenik i mjesto na kojemu je stajao (temenos), a koje se možebitno smatralo svetim. Kako su beneficijari žrtvenike posvećivali prilikom dolaska u postaju ili odlaska iz nje, ${ }^{61}$ možemo nagađati da je dedikant formulaciju o zabrani na spomenik dodao ili kada je došao u Sisciju i primijetio krda divljih svinja oko postaje ili prilikom odlaska kako bi osigurao da se poštuju praksa heliopolskog kulta i svetost prostora.

\section{Simbolika svinje u kultovima starog svijeta}

Formulacija o zabrani svinjetine jedinstvena je; ne nalazimo joj analogiju u opsežnoj epigrafskoj građi čitava Carstva. S obzirom na to da raspolažemo relativno malim korpusom epigrafskih i predmetnih izvora kulta Jupitera Heliopolskog, podatak o zabrani konzumacije svinjetine daje nam uvid u moguće kultne prakse, koje su nam još uvijek uglavnom nepoznate. ${ }^{62}$ Literarni izvori ne

58 GLAVA ̌ 2016: 11.

59 RADMAN-LIVAJA I VUKELIĆ 2016: 211.

60 NELIS-CLÉMENT 2014: 190.

61 GLAVAŠ 2016: 11.

62 Izuzev nekoliko natpisa na kojima se spominje svećenstvo kulta Jupitera Heliopolskog (CIL IV: 36791, 422; CIL III: 11139), nemamo podataka o kultnim službenicima, niti obredima, svetkovinama i sl. 
pružaju nam puno informacija, što je možda posljedica misterijske naravi kulta. Predmetni i epigrafski izvori, premda brojniji, također su šturi glede informacija o kultnoj svakodnevici, stoga nam je žrtvenik iz Siscije iznimno bitan kultni spomenik. Tabu konzumiranja svinjetine u antičkom Egiptu i na Bliskom istoku svakako nije nepoznat, štoviše, predmet je brojnih historiografskih rasprava. ${ }^{63}$ Istraživači se uglavnom slažu da su svinje na tim prostorima pripitomljene u ranom neolitiku, a konzumacija počinje opadati u 1. tisućljeću pr. Kr. ${ }^{64}$ Nesklonost svinjama te, u nekim slučajevima, potpuna prohibicija uzgajanja svinja $i$ konzumiranja njihova mesa rezultat su različitih kulturno-povijesnih okolnosti i ekoloških prilika prostora Egipta, Mezopotamije i Levanta. ${ }^{65}$ Najčešće se govori o nečistoći ${ }^{66}$ kako u praktičnom tako i u simboličkom smislu. Svinja je svejed i strvinar te će kao takva pojesti druge bolesne ili uginule životinje. Svinjski je habitat također izrazito nehigijenski - na velikim se vrućinama svinje hlade blatom te nerijetko vlastitim urinom i izmetom. Konzumiranje takve životinje simbolički će onečistiti i konzumenta, koji takav ne može pred bogove. ${ }^{67}$ Definicija svinje kao nečiste životinje prisutna je i u povijesnim vrelima, od kojih je za ovu tematiku najrelevantniji Levitski zakonik. U propisima o čistom i nečistom $^{68}$ svinja je svrstana pod nečistu životinju te se ne smije ni konzumirati ni dodirivati. Zabranu žrtvovanja svinje nalazimo u knjizi o Izaiji ${ }^{69}$ Strabon, pak, kada piše o anatolskom gradu Komani, spominje zabranu konzumiranja svinjetine, pa čak i dovođenja svinja u grad, sve zbog averzije božice Kibele prema životinji. ${ }^{70}$ Premda se na prostoru Mezopotamije svinjetina u nekim slučajevima konzumirala (s izričitim zabranama konzumiranja na određene dane), izrazito se rijetko žrtvovala bogovima i nikako u hramu..$^{71}$ Sličan je status imala i u Egiptu. Simbolizirala je boga Seta koji je, prema mitu, u obličju svinje ubio Ozirisa. ${ }^{72}$ Svinju su Egipćani smatrali nečistom, a nakon samo jednog dodira životinje morali su se očistiti zajedno s odjećom u rijeci. ${ }^{73}$ Svinja je tabuizirana i u semitskoj mitologiji. Boga Tammuza ili Dumuzida ubila je divlja svinja u libanonskim planinama, kao i Adonisa i frigijskog Atisa. ${ }^{74}$ Štovatelji Adonisa i Atisa ustručavaju

\footnotetext{
63 O navedenoj problematici i daljnim referencama v. COLLINS 2002; REDDING 2015: 326-327.

64 REDDING 2015: 330.

65 HESSE 1990: 197.

66 CAUBET 2002: 222.

67 HOULIHAN 2002: 108.

68 Lev. 11.7.

69 Iz. 66. 3.

70 Geog. 12. 8.9.

71 SCURLOCK 2002: 393.

72 FRAZER 1953: 420a.

$73 \quad$ Ibid: 417.

74 Ibid.: 291.
} 
se stoga jesti svinjetinu. ${ }^{75}$ Moguće je, kako to ističe Frazer, da je životinja koja je ubila božanstvo utjelovljenje istog božanstva te se kao takva smatra svetom. ${ }^{76}$ U tom bi slučaju zabrani konzumiranja i žrtvovanja svinje razlogom bio njezin božanski status. Demosten nam svjedoči o poviku „Svinja Atis! Svinja Atis!“ (Hyes Attes! Hyes Attes!), koji su uzvikivali sljedbenici Kibele i Atisa, ${ }^{77}$ pa je možda i u frigijskom kultu svinja bila sveta. Egipatsko čišćenje u rijeci, smatra Frazer, nakon dodirivanja životinje moglo bi biti povezano s vjerovanjem da se nakon dodira nečeg svetog čovjek mora očistiti. ${ }^{78}$ Dakle, prema Frazerovu mišljenju, moguće je da je kasniji negativan stav prema svinji možda pogrešno tumačenje njezina izvorno svetog statusa. ${ }^{79}$

\section{Zabrana konzumacije svinjetine u kultu Jupitera Heliopolskog}

Izuzev navoda s Pupova žrtvenika, nemamo konkretnih podataka ili indikacija da je unutar kulta Jupitera Heliopolskog postojala službena zabrana konzumiranja ili žrtvovanja svinja. Moguće je da je dedikant samostalno odlučio dodati formulaciju o zabrani zbog osobnog vjerovanja u nečistoću svinje. Međutim, njegovo ime navodi na pretpostavku da je odrastao u okruženju u kojemu taj tabu nije bio uobičajen. U južnoj Galiji, odnosno sjevernoj Italiji, odakle bi dedikant mogao biti podrijetlom, potvrđen je visok udio svinjetine u prehrani, a svinja je prisutna i u duhovnoj svakodnevici i umjetnosti. ${ }^{80}$ Ako prihvatimo da Virilije Pup potječe iz te regije, onda moramo pretpostaviti da se s prohibicijom svinjetine susreo posredno, možda upravo kao sljedbenik kulta Jupitera Heliopolskog. U tom se slučaju svakako treba zapitati je li zabrana svinjetine bila službena politika kulta ili se radilo o blažem slučaju tabuiziranja kao određenog kulturološkog nasljeđa? Odgovor bi mogli dati rezultati istraživanja ritualnih jama heliopolskog hrama u Karnuntu. U najvećoj od njih, jami G11, koja se koristila u periodu 170./180. -210./220. godine, pronađeno je oko 12.000 osteoloških životinjskih ostataka. ${ }^{81}$ Svinjske kosti prisutne su u omjeru manjem od $1 \%$. Prema zaključcima istraživača, jama je vjerojatno služila kao odlagalište životinjskih ostataka, preostalih nakon ritualne gozbe.$^{82}$ Nerazmjer svinjskih i kostiju ostalih životinja ukazuje na „orijentalne“ tradicije, posebno kada se ovi ostaci usporede s nalazima otpadnih

\footnotetext{
Ibid: 311.

76 Ibid: 416.

77 Dem. De Cor. 260.

$78 \quad$ FRAZER 1953: 418.

79 Ibid.: 417.

80 MACKINNON 2001: 649, 659.

81 GAL I KUNST 2013: 336-337.

82 Ibid.
} 
jama iz civilnog dijela Karnunta, u kojima su svinjske kosti dominantne. ${ }^{83}$ Možemo na temelju toga pretpostaviti da je žrtvovanje svinje Jupiteru Heliopolskom bilo zabranjeno, što nam potvrđuju podaci s Pupova spomenika. Također možemo pretpostaviti da konzumacija svinjetine nije bila u potpunosti zabranjena jer su svinjske kosti ipak pronađene u samome hramu. Malen udio kostiju možda sugerira da je konzumiranje svinjetine bilo zabranjeno tijekom kultnih svetkovina ili obreda bogu u čast.

\section{Zaključak}

Žrtvenik Lucija Virilija Pupa, jedini zasad poznati spomenik na kojemu dedikant izričito navodi zabranu žrtvovanja svinje, dragocjen nam je izvor u potrazi za sirijskim elementima kulta Jupitera Heliopolskog koji ne poznajemo izvan rimskog konteksta, $\mathrm{tj}$. nemamo epigrafskih i predmetnih izvora datiranih u period prije prve polovice 1. stoljeća pr. Kr. Analiza ikonografije pokazala je da su semitski atributi najmanje zastupljeni i uglavnom vezani za agrarni karakter božanstva. S druge strane, Pupov žrtvenik jasno upućuje na ,orijentalnu“ kulturološku tradiciju. Kultna praksa izbjegavanja svinjetine kao hrane ili u religijskom smislu, bila ona službena ili neslužbena, svakako nije rimska tradicija. Tabu o svinjetini je, u ovom slučaju, očito kulturološko ili duhovno nasljeđe. Zašto bi inače Lucije Virilije Pup, odrastao u društvu u kojemu je svinjetina uobičajeni dio prehrane, u javnoj posveti sirijskom božanstvu odbacio svinjetinu? Činjenica da je žrtvenik vjerojatno bio u svetištu okruženom šumom i krdima divljih svinja dodatno bi uputila na sljedbenikov otpor prema rimskoj tradiciji. Jedan od razloga isticanja zabrane na natpisu možda je i dedikantova želja da spomene jasno definiranu kultnu praksu kako bi heliopolski kult simbolički odvojio od ostalih u Sisciji. Ako spomenik doista datira u razdoblje dinastije Severa, dedikant je njime možda nastojao i izraziti svoju naklonost vladarima koji su propagirali „orijentalne“ kultove. Spomenik iz Siscije stoga mogao biti pokazatelj da su se, unatoč činjenici da je kult imao dominantne rimske značajke, zadržala neka izvorna vjerovanja. Rimljani su kult Jupitera Heliopolskog, kao što je to bio slučaj s ostalim „orijentalnim“ kultovima, vjerojatno sami oblikovali, svjesno mu dodajući „orijentalne“ značajke poput zabrane žrtvovanja svinje. Strana je tradicija postala dijelom rimske. Stoga se može zaključiti da siscijski žrtvenik jedino svjedočanstvo da je rimska kultna praksa Jupitera Heliopolskog bila protkana egzotičnim, „orijentalnim“ značajkama.

83 Ibid. 


\section{Bibliografija}

\section{Kratice}

Acta Ant. Hung. - Acta Antiqua Academiae Scientarum Hungaricae, Budimpešta.

Acta Arch. Acad. Scient. Hung. - Acta Archaeologica Academiae Scientiarum Hungaricae, Budimpešta.

AE - L'Année Epigraphique, Paris.

AIJug-Antike Inschriften aus Jugoslavien, Zagreb.

ANRW - Aufstieg und Niedergang der römischen Welt, Berlin - New York.

BAAL - Bulletin d'Archéologie et d'Architecture Libanaises, Beyrouth.

CIL - Corpus Inscriptionum Latinarum, Berlin.

Eph. Ep. - Ephemeris Epigrafica, Berlin.

EPRO -Etudes préliminaires aux religions orientales dans l'empire romain, Leiden.

IGLS - Inscriptions grecques et latines de la Syrie, Paris.

ILS - Inscriptiones Latinae Selectae, Berlin.

LIMC-Lexicon iconographicum mythologiae classicae, Zürich - München - Düsseldorf.

\section{Literatura}

BARKÓCZI, László. 1964. The population of Pannonia from Marcus Aurelius to Diocletian. Acta Arch. Acad. Scient. Hung. 16: 257-356.

BOROWSKI, Oded. 2002a. Animals in the Literatures of Syria-Palestine. U A History of the Animal World in the Ancient Near East [Handbook of Oriental Studies, Sect. 1: The Near and Middle East, vol. 64], ur. Billie Jean Collins, 289-309. Leiden - Boston - Köln: E. J. Brill.

BOROWSKI, Oded. 2002b. Animals in the Religion of Syria-Palestine. U A History of the Animal World in the Ancient Near East [Handbook of Oriental Studies, Sect. 1: The Near and Middle East, vol. 64], ur. Billie Jean Collins, 289-309. Leiden - Boston - Köln: E. J. Brill.

BRUNŠMID, Josip. 1905. Kameni spomenici hrvatskoga narodnoga muzeja u Zagrebu. Vjesnik Arheološkog muzeja u Zagrebu 8/1: 37-104.

BRYCE, Trevor. 2014. Ancient Syria: A Three Thousand Year History. Oxford: Oxford University Press.

BUZOV, Marija. 2012. Cults in Roman Siscia. Classica et Christiana 7/1: 57-85.

CAUBET, Annie. 2002. Animals in Syro-Palestinian Art. U A History of the Animal World in the Ancient Near East [Handbook of Oriental Studies, Sect. 1: The Near and Middle East, vol. 64], ur. Billie Jean Collins, 211-237. Leiden - Boston - Köln: E. J. Brill.

COLLINS, Billie Jean (ur.). 2002. A History of the Animal World in the Ancient Near East [Handbook of Oriental Studies, Sect. 1: The Near and Middle East, vol. 64]. Leiden - Boston - Köln: E. J. Brill. 
COLLINS, Billie Jean. 2006. Pigs at the Gate: Hittite Pig Sacrifice in its Eastern Mediterranean Context. Journal of Ancient Near Eastern Religions 6/1: 155-188.

ESS, Margarete van. 2008. First results of the Archaeological Cleaning of the Deep Trench in the Great Courtyard of the Jupiter Sanctuary. U Baalbek-Heliopolis: results of archaeological and architectural research 2002 - 2005, German-Lebanese Colloqium, Berlin 2006, ur. Margarete van Ess, 99-121. Beyrouth: Ministère de la Culture, Dir. Générale des Antiquités.

FICK, Sabine. 1999. Gesichter aus Gold, die den Glanz der Sonne widerspiegeln. U Vom Steinbruch zum Jupitertempel von Heliopolis/Baalbek (Libanon), ur. E. M. Ruprechtsberger, 77-99. Linz: Nordico - Museum der Stadt Linz.

FITZ, Jenő. 1980. Population. U The Archaeology of Roman Pannonia, ur. Alfonz Lengyel, George T. Radan, 141-161. Budimpešta - Kentucky: Akadémiai Kiadó, University Press of Kentucky.

FRAZER, J. George. 1935. The Golden Bough. A Study in Magic and Religion. New York: The Macmillan Company.

FREYBERGER, Klaus Stefan. 2000. Im Licht des Sonnengottes. Deutung und Funktion des sogenannten Bacchus-Tempels im Heiligtum des Jupiter Heliopolitanus in Baalbek. Damaszener Mitteilungen 12: 95-133.

GAL, Erika, Günther Karl KUNST. 2013. Offered to Gods, Eaten by People: Bird Bones from the Sanctuary of Jupiter Heliopolitanus in Carnuntum-Mühläcker (Austria). International Journal of Osteoarchaeology 24/3: 336-346.

GILLMEISTER, Andrzej, Danuta MUSIAL. 2017. Why were the „Oriental Cults“ invented?. Acta. Ant. Hung. 57: 505-514.

GLAVAŠ, Ivo. 2016. Konzularni beneficijariji u rimskoj provinciji Dalmaciji. Zagreb: Ministarstvo kulture.

GRAINGER, John D. 2017. Syrian Influences in the Roman Empire to AD 300. Oxford: Routledge.

HAIDER, Peter W. 1999. Götter und Glaubensvorstellungen in Heliopolis - Baalbek. U Vom Steinbruch zum Jupitertempel von Heliopolis/Baalbek (Libanon), ur. E. M. Ruprechtsberger, 101-143. Linz: Nordico - Museum der Stadt Linz.

HAJJAR, Youssef. 1977. La triade d'Héliopolis - Baalbek, vol. I-II [EPRO 59]. Leiden: E. J. Brill.

HAJJAR, Youssef. 1985. La triade d'Héliopolis-Baalbek: iconographie, théologie culte et sanctuaries. Montreal: Hajjar.

HAJJAR, Youssef. 1988. Heliopolitani Dei. LIMC IV: 573-592.

HAJJAR, Youssef. 1990. Baalbek, grand centre religieux sous l'Empire. $A N R W$ II 18/4: 2458-2508.

HERMAN, Donald. 2006. The coins of the Itureans. Israel Numismatic Research 1: 51-72.

HESSE, Brian. 1990. Pig Lovers and Pig Haters: Patterns of Palestinian Pork Production. Journal of Ethnobiology 10/2: 195-225. 
HOFFILER, Viktor, Balduin SARIA. 1938. Antike Inschriften aus Jugoslavien, vol. I: Noricum und Pannonia Superior. Zagreb: St. Kugli.

HOULIHAN, Patrick F. 2002. Animals in Egyptian Art and Hieroglyphs. U A History of the Animal World in the Ancient Near East [Handbook of Oriental Studies, Sect. 1: The Near and Middle East, vol. 64], ur. Billie Jean Collins, 97-145. Leiden - Boston - Köln: E. J. Brill.

ISAAC, Benjamin. 2017. Empire and Ideology in the Graeco-Roman World. Selected Papers. Cambridge: Cambridge University Press.

JONES, Arnold Hugh Martin. 1971. Cities of the Eastern Roman Provinces. Oxford: Oxford Univerity Press.

KROPP, Andreas J. M. 2009. The cults of Ituraean Heliopolis (Baalbek). Journal of Roman Archaeology 22: 365-380.

KROPP, Andreas J. M. 2010. Jupiter, Venus and Mercury of Heliopolis (Baalbek): the images of the „triad“ and its alleged syncretisms. Syria 87: 229-264.

KROPP, Andreas J. M. 2012. A new altar of the „triad“ of Heliopolis (Baalbek) at the Museum of Adiyaman. Syria 89: 141-150.

KUSSEVEN, Pinar. 2007. The Cult of Jupiter Dolichenus: Origins and Iconography. Magistarski rad, Department of Archaeology and Art History, Bilkent University.

LOHMANN, Daniel. 2010. Giant Strides towards Monumentality - The Architecture of the Jupiter Sanctuary in Baalbek / Heliopolis. Bollettino di Archeologia online I (Volume speciale): 22-29.

MACKINNON, Michael. 2001. High on the Hog: Linking Zooarchaeological, Literary and Artistic Data for Pig Breeds in Roman Italy. American Journal of Archaeology 105/4: 649-673.

MILLAR, Fergus. 2006. Rome, the Greek World and the East, vol. 3. Chapel Hill: The University of North Carolina Press.

MOL, Eva M. 2015. Romanising Oriental cults? A cognitive approach to alterity and religious experience in the Roman cults of Isis. U Romanising Oriental Gods? Religious transformations in the Balkan provinces in the Roman period. New finds and novel perspectives. Proceedings of the International Symposium Skopje, 18-21 September 2013, ur. Aleksandra Nikoloska, Sander Müskens, 89-113. Skopje: Macedonian Academy of Sciences and Arts, University of Leiden.

NELIS-CLÉMENT, Jocelyne. 2000. Les Beneficiarii: militaires et administrateurs au service de l'Empire (I ${ }^{e r}$ s. a.C. $-V I^{e}$ s. p.C.). Bordeaux: Ausonius.

RADMAN-LIVAJA, Ivan, Vlatka VUKELIĆ. 2015. Roman Military Inscriptions from Siscia: An Overview. U Limes XXII. Proceedings of the $22^{\text {nd }}$ international Congress of Roman Frontier studies Ruse, Bulgaria, september 2012, vol. XXII, ur. Lyudmil Vagalinsky, Nicolay Sharankov, 399-405. Sofia: National Archeological Institute with Museum, Bulgarian Academy of Sciences.

RADMAN-LIVAJA, Ivan, Vlatka VUKELIĆ. 2016. Not exactly new epigraphic testimonies for the beneficiarii in Siscia... U The Roman Army between the Alps and the Adriatic, ur. Jana Horvat, 205-213. Ljubljana: Inštitut za arheologijo ZRC SAZU, Založba ZRC. 
RAGETTE, Friedrich. 1980. Baalbek. London: Chatto \& Windus.

REDDING, Richard. 2015. The Pig and the Chicken in the Middle East: Modeling Human Substinence Behavior in the Archaeological Record Using Historical and Animal Husbandry Data. Journal of Archaeological Research 23/4: 325-368.

RENDIĆ-MIOČEVIĆ, Ante. 2005. O kultu Jupitera i Junone na području Siska. Histria Antiqua 13: 241-262.

RENDIĆ-MIOČEVIĆ, Ante, Marina ŠEGVIĆ. 1998. Religions and cults in south Pannonian regions. U: Religions and cults in Pannonia: Exhibition at Székesfehérvár, Csók István Gallery, 15 May - 30 September 1996, ur. Jenő Fitz, 7-17. Stolni Biograd: Fejér Megyei Múzeumok Igazgatósága.

REY-COQUAIS, Jean Paul. 1967. Baalbek et Beqa [IGLS VI]. Paris: Librarie Orientaliste Paul Geuthner.

SANDERS, Charles S. 1902. Jupiter Dolichenus. Journal of the American Oriental Society 23: 84-92.

SAWAYA, Ziad. 2005. Hellenistic, Roman and Byzantine Coins from Baalbek: Preliminary Report and Historical Problems. BAAL 9: 147-160.

SCHOTROFF, Willi. 1982. Die Ituräer. Zeitschrift des Deutschen Palästina - Vereins 98: 125-152.

SCURLOCK, JoAnn. 2002. Animals in ancient Mesopotamian religion. U A History of the Animal World in the Ancient Near East [Handbook of Oriental Studies, Sect. 1: The Near and Middle East, vol. 64], ur. Billie Jean Collins, 361-403. Leiden - Boston - Köln: E. J. Brill.

SELEM, Petar. 1980. Les religions orientales dans la Pannonie Romaine [EPRO 85]. Leiden: E. J. Brill.

SELEM, Petar, Inga VILOGORAC BRČIĆ. 2018. ROMIC II.: Religionum Orientalium monumenta et inscriptiones ex Croatia II. [Znakovi i riječi 5 - Signa et litterae V]. Zagreb: FF press.

SEYRIG, Henry. 1954. Questions héliopolitaines [Antiquités syriennes 57]. Syria 31: 68-98.

SEYRIG, Henry. 1971. Le culte du Soleil en Syrie a l'époque romaine [Antiquités syriennes 95]. Syria 48: 337-373.

SINOBAD, Marko. 2010. Jupiter i njegovi štovatelji u svjetlu epigrafskih izvora na području Hrvatske. Opuscula Archaeologica 34: 145-229.

SPEIDEL, Michael Alexander. 2005. Early Roman rule in Commagene. Scripta Classica Israelica XXIV: 85-100.

STEIGBERBER, Eva, Barbara TOBER. 2013. The Sanctuary of Iuppiter Heliopolitanus in Carnuntum: Destruction or Demolition. A Case Study. U Destruction: Archaeological, philological and historical perspectives, ur. Jan Driessen, 435-449. Louvain-la-Neuve: Presses Universitaires de Louvain.

ŠAŠEL KOS, Marjeta. 2017. The Sisciani in the Roman Empire. U Studia Europaea Gnesnensia 16/2017, ur. Leszek Mrozewicz, 173-205. Gniezno: Instytut Kultury Europejskiej UAM. 
ŠEGVIĆ, Marina. 1986. Antički kultovi u Sisku i Topuskome. Izdanja Hrvatskog arheološkog društva 10: 95-101.

TOUTAIN, Jules. 1911. Les cultes païens dans l'Empire romain. Première Partie: Les Provinces Latines. Tome II: Les cuites orientaux. Pariz: Leroux.

VERSLUYS, Miguel John. 2013. Orientalising Roman Gods. U Panthée: Religious Transformations in the Graeco-Roman Empire, ur. Laurent Bricault, Corinne Bonnet, 235-261. Leiden - Boston: Brill.

VUKELIĆ, Vlatka. 2011. Povijest sustavnih arheoloških istraživanja u Sisku od 16. stoljeća do 1941. godine. Doktorski rad, Hrvatski studiji Sveučilišta u Zagrebu.

WIEGAND Theodor. 1921. Baalbek. Ergebnisse der Ausgrabungen und Untersuchungen in den Jahren 1898 bis 1905. Berlin: W. de Gruyter.

ZANINOVIĆ, Marin. 1981. Siscia u svojim natpisima. Izdanja Hrvatskog Arheološkog društva 6: 201-207. 


\section{The Cult of Jupiter Heliopolitanus in Siscia}

The cult of Jupiter Heliopolitanus spread from ancient Heliopolis, modern day Baalbek in Lebanon, to the western provinces of the Roman Empire in the first half of the $2^{\text {nd }}$ century. The cult image of the god is known only from the Roman Imperial period, for there are no depictions dating to the period before the first half of the $1^{\text {st }}$ century B. C. Siscia is known to have been popular with "Orientals", and many found their new home in this Pannonian transportation and trade hub. Evidence of the cults of Mithra, Cybele, Attis, Isis, Serapis, Jupiter Amon and the Thracian horseman have all been found here in both epigraphic sources and archaeological materials. One monument, the altar of the beneficiarius consularis Lucius Virilius Pupus, testifies to the cult of Jupiter Heliopolitanus in Siscia. At the end of the votive inscription, the dedicant specified that pigs are not to be sacrificed on this altar. Such a formula is unique when it comes to epigraphic sources. This altar is the only known monument from the Roman Imperial period on which we find a ban on sacrificing pigs. It is also the only monument that provides certain information about the practices of the cult of Jupiter Heliopolitanus. The prohibition against pigs and pig taboos are well known to have been widespread among the people of "Oriental" origin at that time. Pigs were considered impure, both literally and symbolically. Since we know very little about the rituals and cult practices of the Heliopolitan cult, this information raises the question of whether this "Oriental" tradition was an official cult policy. If it was, what would it mean in terms of determining the "oriental" in "oriental" cults? Was the cult of Jupiter Heliopolitanus more "Roman" in nature? This paper aims to contribute to solving the problem of continuity of "Oriental" cults and reinterpreting the process of Romanization of deities of "Oriental" origin.

Key words: Jupiter Heliopolitanus, Siscia, "Oriental” cults, altar, inscription, pig taboo, authenticity.

Ključne riječi: Jupiter Heliopolski, Siscija, ,orijentalni“ kultovi, žrtvenik, natpis, zabrana svinjetine, autentičnost.

Tea Fumić

Borisa Brnada 14

HR-44000 Sisak

teafumic1@gmail.com 


\section{FILOZOFSKI FAKULTET SVEUČILIŠTA U ZAGREBU \\ ZAVOD ZA HRVATSKU POVIJEST \\ INSTITUTE OF CROATIAN HISTORY \\ INSTITUT FÜR KROATISCHE GESCHICHTE}

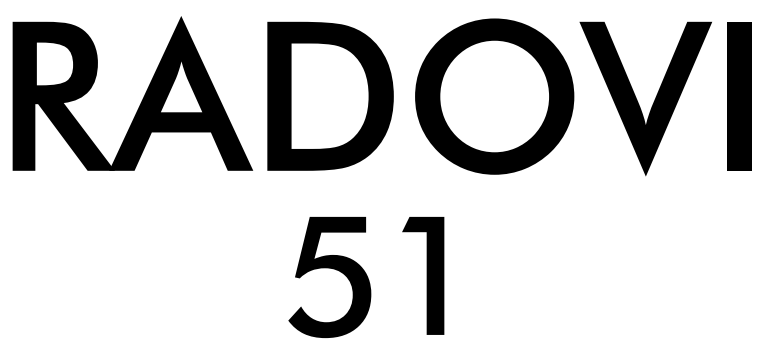

BROJ 2

ZAVOD ZA HRVATSKU POVIJEST

FILOZOFSKOGA FAKULTETA SVEUČILIŠTA U ZAGREBU

\section{FF press}

ZAGREB 2019. 


\title{
RADOVI ZAVODA ZA HRVATSKU POVIJEST FILOZOFSKOGA FAKULTETA SVEUČILIŠTA U ZAGREBU
}

\author{
Knjiga 51, broj 2
}

\author{
Izdavač / Publisher \\ Zavod za hrvatsku povijest \\ Filozofskoga fakulteta Sveučilišta u Zagrebu \\ FF-press \\ Za izdavača / For Publisher \\ Vesna Vlahović Štetić \\ Glavni urednik / Editor-in-Chief \\ Inga Vilogorac Brčić \\ Izvršni urednik / Executive Editor \\ Kornelija Jurin Starčević \\ Uredništvo / Editorial Board
}

Jasmina Osterman (stara povijest/ancient history), Trpimir Vedriš (srednji vijek/medieval history), Hrvoje Petrić (rani novi vijek/early modern history), Željko Holjevac (moderna povijest/ modern history), Tvrtko Jakovina (suvremena povijest/contemporary history), Silvija Pisk

(mikrohistorija i zavičajna povijest/microhistory and local history),

Zrinka Blažević (teorija i metodologija povijesti/theory and methodology of history)

Međunarodno uredničko vijeće / International Editorial Council

Denis Alimov (Sankt Peterburg), Živko Andrijašević (Nikšić), Csaba Békés (Budapest), Rajko

Bratož (Ljubljana), Svetlozar Eldarov (Sofija), Toni Filiposki (Skopje), Aleksandar Fotić

(Beograd), Vladan Gavrilović (Novi Sad), Alojz Ivanišević (Wien),

Egidio Ivetić (Padova), Husnija Kamberović (Sarajevo), Karl Kaser (Graz),

Irina Ognyanova (Sofija), Géza Pálffy (Budapest), Ioan-Aurel Pop (Cluj),

Nade Proeva (Skopje), Alexios Savvides (Kalamata), Vlada Stanković (Beograd),

Ludwig Steindorff (Kiel), Peter Štih (Ljubljana)

Izvršni urednik za tuzemnu i inozemnu razmjenu /

Executive Editor for Publications Exchange

Martin Previšić

Tajnik uredništva / Editorial Board Assistant

Dejan Zadro

Adresa uredništva/Editorial Board address

Zavod za hrvatsku povijest, Filozofski fakultet Zagreb, Ivana Lučića 3, HR-10 000, Zagreb Tel. ++385(0)1 6120191

Časopis izlazi jedanput godišnje / The Journal is published once a year

Časopis je u digitalnom obliku dostupan na / The Journal in digital form is accessible at Portal znanstvenih časopisa Republike Hrvatske „Hrčak“ http://hrcak.srce.hr/radovi-zhp

Financijska potpora za tisak časopisa / The Journal is published with the support by Ministarstvo znanosti, obrazovanja i športa Republike Hrvatske

Časopis je indeksiran u sljedećim bazama / The Journal is indexed in the following databases: Directory of Open Access Journals, EBSCO, SCOPUS, ERIH PLUS, Emerging Sources Citation Index - Web of Science 


\title{
Naslovna stranica / Title page by Marko Maraković
}

\section{Grafičko oblikovanje i računalni slog / Graphic design and layout Marko Maraković}

\author{
Lektura / Language editors \\ Samanta Paronić (hrvatski / Croatian) \\ Edward Bosnar (engleski / English)
}

Tisak / Printed by

Tiskara Zelina, Sv. Ivan Zelina

Naklada / Issued

200 primjeraka / 200 copies

Ilustracija na naslovnici

Muza Klio (Alexander S. Murray, Manual of Mythology, London 1898)

Časopis je u digitalnom obliku dostupan na Portalu znanstvenih časopisa Republike Hrvatske ,Hrčak“ http://hrcak.srce.hr/radovi-zhp

The Journal is accessible in digital form at the Hrcak - Portal of scientific journals of Croatia http://hrcak.srce.hr/radovi-zhp 